\title{
EFFECT OF SUBCOOLING IN VCRS AS COMPARED TO SIMPLE VCRS SYSTEM
}

\author{
Taliv Hussain; Arjun Sharma; Navin; Rahul Wandra; Gaurav Roy \\ Department of Mechanical Engineering, \\ Lovely Professional University Phagwara, \\ Punjab (India) -144402 \\ Email:taliv.17727@1pu.co.in \\ Phone no: 08283836492
}

\begin{abstract}
Decreasing the consumption of power in a vapour compression air conditioning system with increase in refrigeration effect and reduction of compressor work is a major concern and challenging problem especially in the area where extreme weather conditions of about $50^{\circ} \mathrm{C}$ exists. This extreme weather condition not only decreases the performance of an air condenser but also increases the electrical power consumption. In this paper we have analysed subcooling by heat exchanger, air cooled condenser and formulate the performance of each on VCRS system. A set-up of vapour compression air conditioning has been built and is paired with the heat exchanger and normal air condenser. Both the Heat exchanger and air condenser are connected in series. The effect of these two on the cycle performance at different ambient conditions have been measured. Experimental results show that the use of subcooling by heat exchanger compared with simple vapour compression system will improve the COP. The COP of subcooled VCRS is 3.99 where as the COP of simple VCRS is 3.Thus the COP increase is about $33.3 \%$ in subcooled vapour compression refrigeration system as compare to simple vapour compression refrigeration system.
\end{abstract}

Keywords: Vapour compression refrigeration system, COP, subcooling.

\section{INTRODUCTION}

Until the beginning of the nineteen century, man's energy sources were mainly human muscle power and some other non-conventional energy(wind) sources but during last few decade, there has been rapid increase in demand of energy consumption because of increasing population .The resulting impact of Such energy consumption trend on the local environment has been massive with far-reaching consequences which can be seen in the form of rising global temperature and sea level .India became the world's third largest producer of electricity in the year 2013 with $4.8 \%$ global share in electricity generation which means more burning of fossil fuels as $70 \%$ of India's energy generation is from fossil fuel with coal accounting for $40 \%$ followed by crude oil and natural gas. So it has become indispensable thing for today's government to find energy efficient systems which will consume less power for the same amount of work. In this project we have concentrated our study on subcooling by heat exchanger (HX) , and simple air conditioning systems(VCRS) using $\mathrm{R} 134 \mathrm{a}$ (tetraflouro ethane) as refrigerant and found out experimentally the performance improvement in COP and power consumption using comparison between subcooled by heat exchanger(HX) and air cooled air conditioning systems .Typically Air cooled condenser are commonly used in almost all residential buildings and commercial offices. Increase in average temperature due to global warming is also increasing the demand of these air conditioners. With the increase in ambient air temperature $\left(\sim 30-46^{\circ} \mathrm{C}\right)$ there is a drop in COP of most of air cooled air conditioners units by about 35-45\% which further increases the electricity consumption. Further the use of heat exchangers is widespread in commercial refrigeration. The heat exchangers are often employed as a means for protecting system components, by helping to ensure single-phase liquid to the expansion device and single-phase vapour to the compressor. As a result of employing this intracycle heat exchange, the high pressure refrigerant is subcooled at the expense of superheating the vapour entering the compressor.

\section{LITERATURE REVIEW}

Groseclose et al. [1954] showed that the cost of the water-cooled condensers with cooling towers and the evaporative cooling condensers were almost the same. Nevertheless, the conventional water-cooled condensers involved a cooling tower, which also imply a larger installation space and extra power for fan and pump .Gosney [1982] dimensionless equations for COP and volumetric-capacity effectiveness of the internal heat exchange. A 
thorough" discussion of liquid-subcooling and vaporsuperheating effects .Webb [1984] developed a unified theoretical treatment of evaporative systems: cooling towers, evaporative coolers and evaporative condensers. His model considered the effect of the variation in temperature of the deluge water in an evaporative cooler, but stated that for an evaporative condenser the film temperature remains essentially constant due to the fact that the variation in the refrigerant temperature is negligibly small. McLinden [1990] performed analysis of llsl-hx cycles employing a semi-theoretical cycle simulation model, which included representation for the evaporator and condenser, and temperature profile of the sink and source heat transfer fluids. He concluded that fluids having a high vapour heat capacity can simultaneously achieve high capacity and efficiency. presented simulation results showing different relative rankings of refrigerants studied depending on the cycle used for performance comparison (llsl-hx or reversed Rankine cycle).P.A. Domanski and D.A. Didion [1992] paper presents a theoretical evaluation of the performance effects resulting from the installation of a liquid line/ suction line heat exchanger (llsl·hx). It examines cycle the parameters and refrigerant thermodynamic properties that determine whether the installation results in improvement of COP and volumetric capacity. The study showed that the benefit of application of the Jlsl-hx depends on a combination of operating conditions and fluid properties, heat capacity, latent heat, and coefficient of thermal expansion with heat capacity being the most influential property. Fluids that perform well in the basic cycle are marginally affected by the 1lsl-hx, and the impact on the Coefficient of Performance and volumetric capacity may be either positive or negative. Fluids performing poorly in the basic cycle benefit from the llsl.hx installation through increase of the Coefficient of Performance and volumetric capacity .Linton et al. [1992] experimentally investigated the effect of condenser liquid subcooling on a refrigeration system performance. Results showed that the cooling COP and refrigeration capacity of all three refrigerants benefited from subcooling increase (from $6^{\circ} \mathrm{C}$ to $\left.18^{\circ} \mathrm{C}\right)$ : R134a (12.5\%), R12 (10.5\%) and R152a $(10 \%)$, while condensing temperature was kept artificially constant. Subcooling has also been subject of publications related to automotive air conditioners. These systems are usually equipped with either a high-side liquid receiver or a low-side accumulator in order to absorb fluctuations in refrigerant charge.

\section{EXPERIMENTAL SET-UP}

In this project we have concentrated our study on the domestic air conditioner ie. subcooled VCRS by employing heat exchanger and Simple VCRS. The performance of the subcooled system is elevated by installing heat exchanger between suction and discharge line. In case of simple VCRS system air cooled condenser has been used .The experimental setup (figure 1 and figure 2) consists of a single stage vapour compression system with the basic components i.e. evaporator, compressor, expansion device, condensers and a coil heat exchanger. The coil type heat exchanger has been attached in series after condenser and parallel to the suction line before compressor. The shifting of air cooled air conditioning system to the subcooled i.e.(system with heat exchanger) air conditioning system is done with the help of the system of hand set valve attached. The whole experiment is carried out on R134a (tetra flouroethane) which is used as refrigerant in setup.

After taking the reading with subcooled system i.e.(system with heat exchanger), we perform the same experiment with air cooled condenser VCRS .Ammeter and voltmeter are used to measure the electrical current and voltage of input power respectively. The bourdon pressure gauges are used to measure the suction (inlet) and discharge (outlet) pressure of compressor. Temperatures of refrigerant and the ambient air at different points are measured by use of RTD PT100 type thermocouples. Before temperature measurement, the surface of the tubes are polished for removing any type of dust or rust and then the thermocouples are laid own onto the surface. Insulation tapes are wrapped around the copper tubes to prevent any heat losses to ambient air.

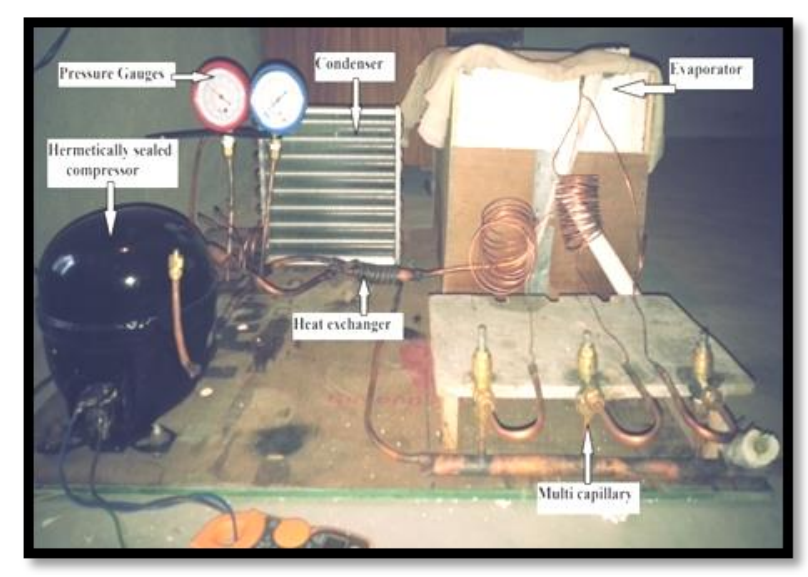




\section{Asia Pacific Journals}

Figure 1: Experimental set-up with subcooled VCRS with heat exchanger and air cooled condenser

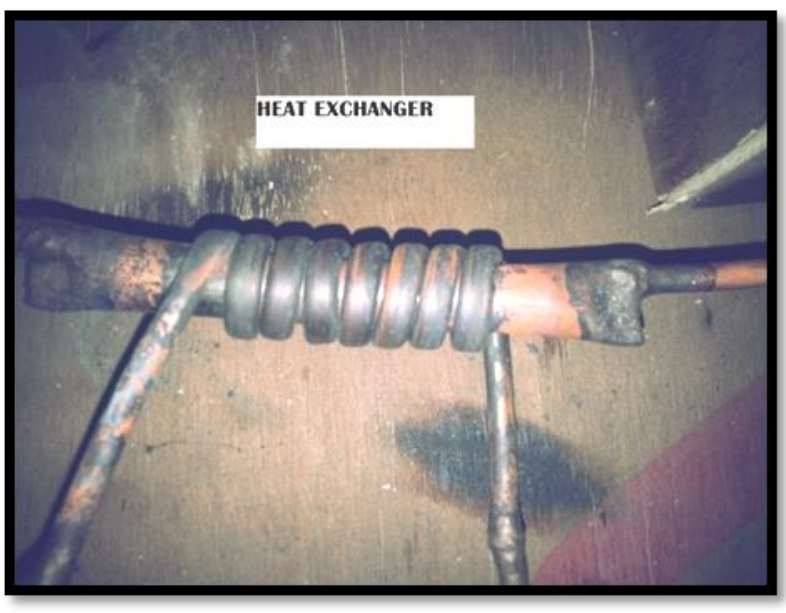

Figure:2 Experimental set-up of coil heat exchanger

\section{EXPERIMENTAL RESULTS AND DISCUSSIONS}

In order to estimate the effect of subcooled VCRS system i.e.(system with heat exchanger) and air cooled conditioning system i.e.(simple VCRS) and also comparing the results of both subcooled VCRS system and air cooled condenser, experimental tests are performed in two subsequent stages. In the first stage of the experiment, air-cooled condenser is used. After getting the data, in the second stage subcooled VCRS system is used under the same ambient conditions. Data are recorded after a steady state condition is achieved in the system and the properties of refrigerant (R134a) and air remained constant (after $15 \mathrm{~min}$ ). Experimental tests are performed at three ambient temperatures i.e. $29^{\circ} \mathrm{C}, 33^{\circ} \mathrm{C}$ and $39^{\circ} \mathrm{C}$ in order to have better understanding of the system behaviour under different climatic conditions.

\begin{tabular}{|c|c|c|c|c|}
\hline \multirow[t]{2}{*}{ Parameter } & \multirow[t]{2}{*}{ Symbol } & \multirow[t]{2}{*}{ Unit } & \multicolumn{2}{|c|}{$\begin{array}{l}\text { Ambient air Temperature at } \\
\text { DBT-29 }{ }^{\circ} \mathrm{C}, \text { WBT }-21^{\circ} \mathrm{C}, \text { RH - } \\
50 \%\end{array}$} \\
\hline & & & $\begin{array}{l}\text { Subcooled } \\
\text { VCRS }\end{array}$ & $\begin{array}{l}\text { Air Cooled } \\
\text { Condenser }\end{array}$ \\
\hline $\begin{array}{l}\text { Evaporator } \\
\text { Absolute } \\
\text { pressure }\end{array}$ & $\mathbf{P}_{\text {eva }}$ & bar & 2.91 & 3.98 \\
\hline $\begin{array}{l}\text { Condenser } \\
\text { Absolute } \\
\text { pressure }\end{array}$ & pcon & bar & 10.75 & 18.49 \\
\hline $\begin{array}{l}\text { Evaporator } \\
\quad \text { exit } \\
\text { temperature }\end{array}$ & $\mathbf{T}_{1}$ & ${ }^{\circ} \mathrm{C}$ & -15 & 15 \\
\hline $\begin{array}{l}\text { Compressor } \\
\quad \text { exit } \\
\text { temperature }\end{array}$ & $\mathbf{T}_{2}$ & ${ }^{\circ} \mathrm{C}$ & 25 & 71 \\
\hline $\begin{array}{c}\text { Condenser } \\
\text { exit } \\
\text { temperature }\end{array}$ & $\mathbf{T}_{3}$ & ${ }^{\circ} \mathrm{C}$ & 19 & 52 \\
\hline $\begin{array}{l}\text { Evaporator } \\
\text { inlet } \\
\text { temperature }\end{array}$ & T4 & & 5 & 8 \\
\hline $\begin{array}{l}\text { Total } \\
\text { electric } \\
\text { current }\end{array}$ & I & Amp & 1.4 & 2.12 \\
\hline $\begin{array}{l}\text { Total } \\
\text { electric } \\
\text { voltage }\end{array}$ & V & Volt & 225 & 225 \\
\hline
\end{tabular}

Table 1: Result obtained at $29^{\circ} \mathrm{C}$ ambient temperature 
ELK

Asia Pacific Journals

\begin{tabular}{|c|c|c|c|c|}
\hline \multirow[t]{2}{*}{ Parameter } & \multirow[t]{2}{*}{ Symbol } & \multirow[t]{2}{*}{ Unit } & \multicolumn{2}{|c|}{$\begin{array}{l}\text { Ambient air Temperature at } \\
\text { DBT-33 }{ }^{\circ} \mathrm{C}, \mathrm{WBT}^{\circ}-6^{\circ} \mathrm{C}, \\
\text { RH }-57 \%\end{array}$} \\
\hline & & & $\begin{array}{l}\text { Subcooled } \\
\text { VCRS }\end{array}$ & $\begin{array}{l}\text { Air Cooled } \\
\text { Condenser }\end{array}$ \\
\hline $\begin{array}{l}\text { Evaporator } \\
\text { Absolute } \\
\text { pressure }\end{array}$ & $\mathbf{P}_{\text {eva }}$ & bar & 3.41 & 5.1 \\
\hline $\begin{array}{l}\text { Condenser } \\
\text { Absolute } \\
\text { pressure }\end{array}$ & pcon & bar & 10.97 & 21.42 \\
\hline $\begin{array}{l}\text { Evaporator } \\
\text { exit } \\
\text { temperature }\end{array}$ & $\mathbf{T}_{1}$ & ${ }^{\circ} \mathrm{C}$ & -7 & 18 \\
\hline $\begin{array}{l}\text { Compressor } \\
\quad \text { exit } \\
\text { temperature }\end{array}$ & $\mathbf{T}_{2}$ & ${ }^{\circ} \mathrm{C}$ & 40 & 75 \\
\hline $\begin{array}{l}\text { Condenser } \\
\text { exit } \\
\text { temperature }\end{array}$ & $\mathbf{T}_{3}$ & ${ }^{\circ} \mathrm{C}$ & 35 & 62 \\
\hline $\begin{array}{l}\text { Evaporator } \\
\text { inlet } \\
\text { temperature }\end{array}$ & T4 & ${ }^{\circ} \mathrm{C}$ & 5 & 13 \\
\hline $\begin{array}{l}\text { Total } \\
\text { electric } \\
\text { current }\end{array}$ & I & Amp & 1.87 & 2.24 \\
\hline $\begin{array}{l}\text { Total } \\
\text { electric } \\
\text { voltage }\end{array}$ & V & Volt & 225 & 225 \\
\hline
\end{tabular}

ELK Asia Pacific Journals - Special Issue

ISBN: 978-81-930411-4-7

\begin{tabular}{|c|c|c|c|c|}
\hline \multirow[t]{2}{*}{ Parameter } & \multirow{2}{*}{$\begin{array}{c}\text { Sym } \\
\text { bol }\end{array}$} & \multirow[t]{2}{*}{ Unit } & \multicolumn{2}{|c|}{$\begin{array}{l}\text { Ambient air Temperature at } \\
\text { DBT-39 }{ }^{\circ} \mathrm{C}, \mathrm{WBT}-32^{\circ} \mathrm{C}, \mathrm{RH}- \\
61 \%\end{array}$} \\
\hline & & & $\begin{array}{l}\text { Subcooled } \\
\text { VCRS }\end{array}$ & $\begin{array}{l}\text { Air Cooled } \\
\text { Condenser }\end{array}$ \\
\hline $\begin{array}{l}\text { Evaporator } \\
\text { Absolute } \\
\text { pressure }\end{array}$ & $\mathbf{P}_{\text {eva }}$ & bar & 4.33 & 5.52 \\
\hline $\begin{array}{l}\text { Condenser } \\
\text { Absolute } \\
\text { pressure }\end{array}$ & $\mathbf{p}_{\text {con }}$ & bar & 12.44 & 26 \\
\hline $\begin{array}{l}\text { Evaporator } \\
\quad \text { exit } \\
\text { temperature }\end{array}$ & $\mathbf{T}_{\mathbf{1}}$ & ${ }^{\circ} \mathrm{C}$ & -2 & 20 \\
\hline $\begin{array}{l}\text { Compressor } \\
\text { exit } \\
\text { temperature }\end{array}$ & $\mathbf{T}_{2}$ & ${ }^{\circ} \mathrm{C}$ & 55 & 81 \\
\hline $\begin{array}{l}\text { Condenser } \\
\text { exit } \\
\text { temperature }\end{array}$ & $\mathbf{T}_{3}$ & ${ }^{\circ} \mathrm{C}$ & 51 & 71 \\
\hline $\begin{array}{l}\text { Evaporator } \\
\text { inlet } \\
\text { temperature }\end{array}$ & T4 & ${ }^{\circ} \mathrm{C}$ & 11 & 15 \\
\hline $\begin{array}{l}\text { Total } \\
\text { electric } \\
\text { current }\end{array}$ & I & Amp & 2 & 2.31 \\
\hline $\begin{array}{l}\text { Total } \\
\text { electric } \\
\text { voltage }\end{array}$ & V & Volt & 225 & 225 \\
\hline
\end{tabular}

Table 3: Result obtained at $39^{\circ} \mathrm{C}$ ambient temperature 


\section{ELK}

Asia Pacific Journals
ELK Asia Pacific Journals - Special Issue

ISBN: 978-81-930411-4-7

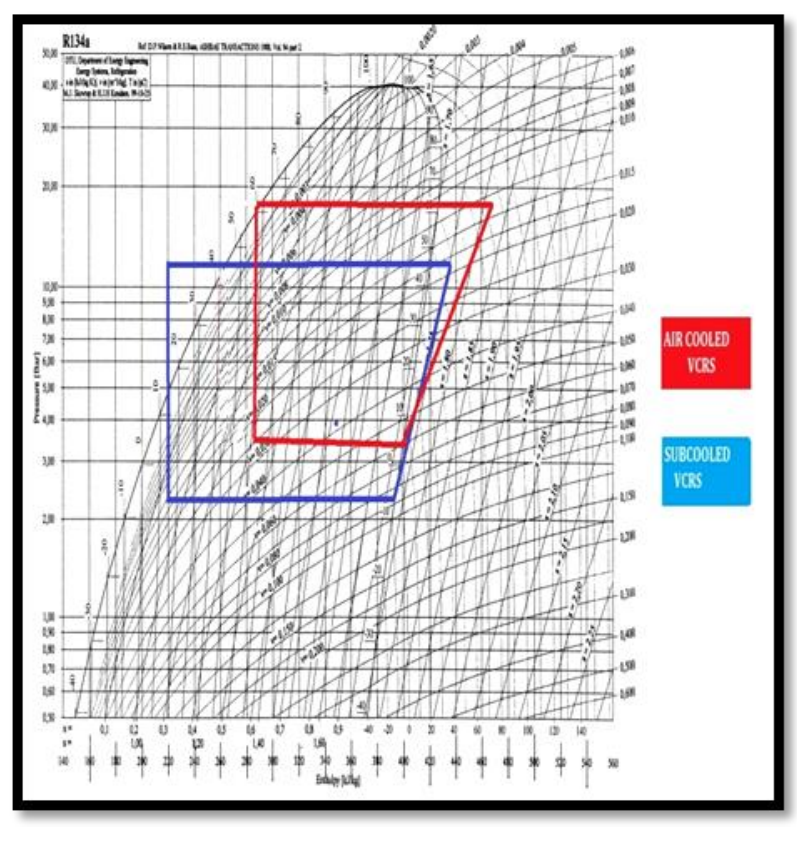

Figure 3: Pressure-enthalpy (P-h) diagram for subcooled VCRS and air cooled air conditioning system at $29^{\circ} \mathrm{C}$ ambient air temperature.

\section{CALCULATION AND RESULTS}

Based on the experimental results, thermodynamic properties of the refrigerant at different points in the cycle are obtained using the P-H chart of refrigerant R-134a and the parameters such as mass flow rate, cooling capacity and $\mathrm{COP}$ of the system are calculated from the equations:

a. Compressor Work Wc $=\mathrm{V} * \mathrm{I}=m_{r e f} *(\mathrm{~h} 2-\mathrm{h} 1)$

b. Mass flow rate of refrigerant $m_{r e f}=\frac{\text { Wc }}{(\text { h2 } 2 \text {-h1 })}$

c. Cooling effect produced $\mathrm{Qr}=m_{r e f} *(\mathrm{~h} 1-\mathrm{h} 4)$

d. $\mathrm{COP}=\frac{\mathrm{QP}_{\mathrm{T}}}{\mathrm{Wc}}$ where,

$\mathrm{h} 1$ = enthalpy of refrigerant at inlet of compressor in $\mathrm{kj} / \mathrm{kg}$ $\mathrm{h} 2=$ enthalpy of refrigerant at exit of compressor in $\mathrm{kj} / \mathrm{kg}$ $\mathrm{h} 3=$ enthalpy of refrigerant at exit of the condenser in $\mathrm{kj} / \mathrm{kg}$ $\mathrm{h} 4=$ enthalpy of refrigerant at entry of evaporator in $\mathrm{kj} / \mathrm{kg}$.

The voltage meter and ampere meter attached in the experimental set-up. Using this voltage and ampere reading, work done of the compressor is obtained Table 4, 5 and 6 shows the results obtained from the observations recorded at three different ambient air temperature i.e. $29^{\circ} \mathrm{C}, 33^{\circ} \mathrm{C}$ and $39^{\circ} \mathrm{C}$.

TABLE 4: RESULTS OF THE EXPERIMENT AT AMBIENT AIR TEMPERATURE OF $29^{\circ} \mathrm{C}$

\begin{tabular}{|c|c|c|c|c|}
\hline \multicolumn{5}{|c|}{ Performance Results of Air Conditioner $\left(\mathrm{T}_{\mathrm{amb}}-2^{\circ} \mathrm{C}\right)$} \\
\hline Parameter & Unit & $\begin{array}{c}\text { Air Cooled } \\
\text { VCRS }\end{array}$ & $\begin{array}{c}\text { Subcooled } \\
\text { VCRS }\end{array}$ & Variation( $(\%)$ \\
\hline Compressor Work, $\mathrm{W}_{\mathrm{c}}$ & Watt & 447 & 315 & $-34 \%$ \\
\hline $\begin{array}{l}\text { Coefficient of } \\
\text { performance }\end{array}$ & & 3 & 3.9 & $26 \%$ \\
\hline
\end{tabular}

. In case of subcooled VCRS total compressor work reduces about $34 \%$. There is an increase of $26 \%$ in the COP of subcooled VCRS as compare to aircooled VCRS 


\section{ELK}

Asia Pacific Journals

\begin{tabular}{|c|c|c|c|c|}
\hline \multicolumn{3}{|c|}{ Performance Results of Air Conditioner $\left(\mathbf{T}_{\mathbf{a m b}}-\mathbf{3 3}^{\mathbf{}} \mathbf{C}\right)$} \\
\hline Parameter & Unit & $\begin{array}{c}\text { Air } \\
\text { Cooled } \\
\text { VCRS }\end{array}$ & $\begin{array}{c}\text { Subcooled } \\
\text { VCRS }\end{array}$ & Variation(\%) \\
\hline $\begin{array}{c}\text { Compressor Work, } \\
\text { W }_{\mathrm{c}}\end{array}$ & Watt & 504 & 420.75 & $-18 \%$ \\
\hline $\begin{array}{c}\text { Coefficient of } \\
\text { performance } \\
\text { COP }\end{array}$ & & 2.62 & 2.8 & $6 \%$ \\
\hline
\end{tabular}

TABLE 5: RESULTS OF THE EXPERIMENT AT AMBIENT AIR TEMPERATURE OF $33^{\circ} \mathrm{C}$

Performance Results of Air Conditioner $\left(\mathrm{T}_{\mathrm{amb}}-\mathbf{3 9}^{\circ} \mathrm{C}\right)$

\begin{tabular}{|c|c|c|c|c|}
\hline Parameter & Unit & $\begin{array}{c}\text { Air } \\
\text { Cooled } \\
\text { VCRS }\end{array}$ & $\begin{array}{c}\text { Subcooled } \\
\text { VCRS }\end{array}$ & $\begin{array}{c}\text { Variation } \\
(\%)\end{array}$ \\
\hline $\begin{array}{c}\text { Compressor Work, } \mathrm{W}_{\mathrm{c}} \\
\text { Veefficient of } \\
\text { performance } \\
\text { COP }\end{array}$ & Watt & 519.75 & 450 & $-14 \%$ \\
\hline
\end{tabular}

ELK Asia Pacific Journals - Special Issue

ISBN: 978-81-930411-4-7

At $33^{\circ} \mathrm{C}$ ambient air temperature, Subcooled VCRS total shows a reduction of $18 \%$ in compressor work. There is an increase of $6 \%$ in the COP of Subcooled VCRS as compare to air cooled condenser which is less by $32 \%$ than at $29^{\circ} \mathrm{C}$.

\section{TABLE 6: RESULTS OF THE EXPERIMENT AT} AMBIENT AIR TEMPERATURE OF $39^{\circ} \mathrm{C}$

At $39^{\circ} \mathrm{C}$ ambient air temperature, Subcooled VCRS total shows a reduction of $14 \%$ in compressor work. There is an increase of $3 \%$ in the COP of Subcooled VCRS as compare to air cooled condenser.

\section{Effect of ambient temperature on Compressor work}

Figure 4 shows the variation of compressor work for subcooled and air cooled VCRS in terms of ambient air temperature. As seen from the graph, with increase in air temperature compressor work is increased and there is considerable difference between performance of two systems. The compressor work for the subcooled VCRS is significantly low as compare to air cooled VCRS. In air cooled system, condenser rejects heat to the external fluid i.e. air, while in subcooled system the high pressure refrigerant is subcooled at the expense of superheating the vapour entering the compressor. Therefore the saturation pressure is decreased in case of subcooled VCRS which in turn lowers the compressor power for same cooling capacity. Also with the increase in ambient air temperature the heat rejection rate from the condenser decreases which puts an excessive load on to the compressor. 


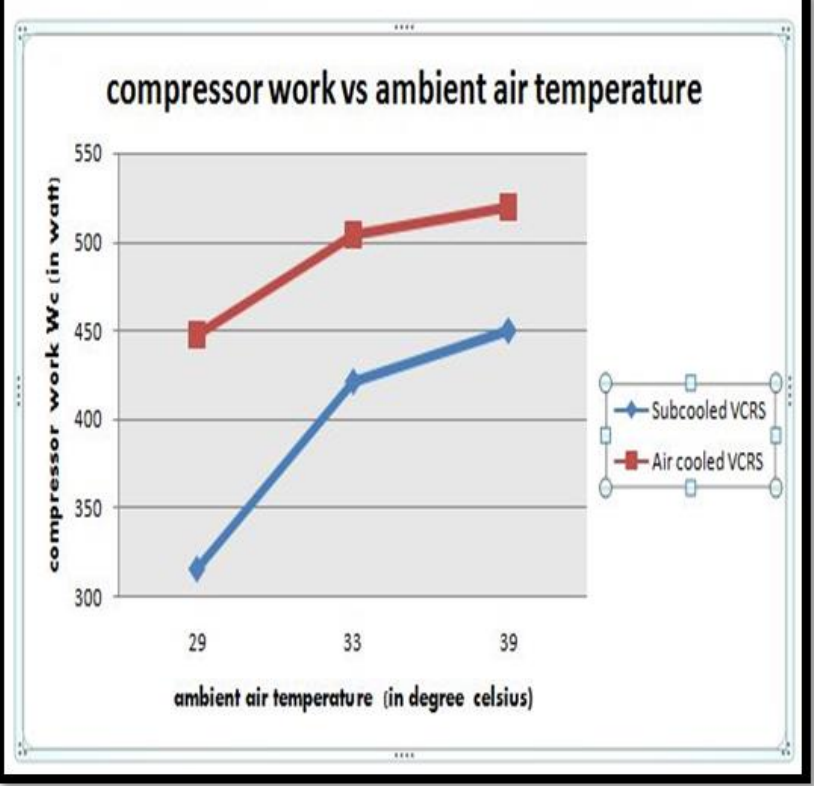

Figure 4: compressor work variation at different ambient air temperature

\section{EFFECT OF AMBIENT TEMPERATURE ON COP}

Figure 5 shows the variation of COP with ambient air temperature for subcooled VCRS and air cooled VCRS. As the experimental results show that there is decrease in COP with the increase in ambient air temperature. Also the COP of subcooled VCRS is more then the air cooled VCRS because of high cooling effect and low compressor work. The difference between two curves is very large at $29^{\circ} \mathrm{C}$ and it decreases as ambient air temperature increases. This decrease in COP is due to the reduction in cooling load with increase in ambient air temperature.

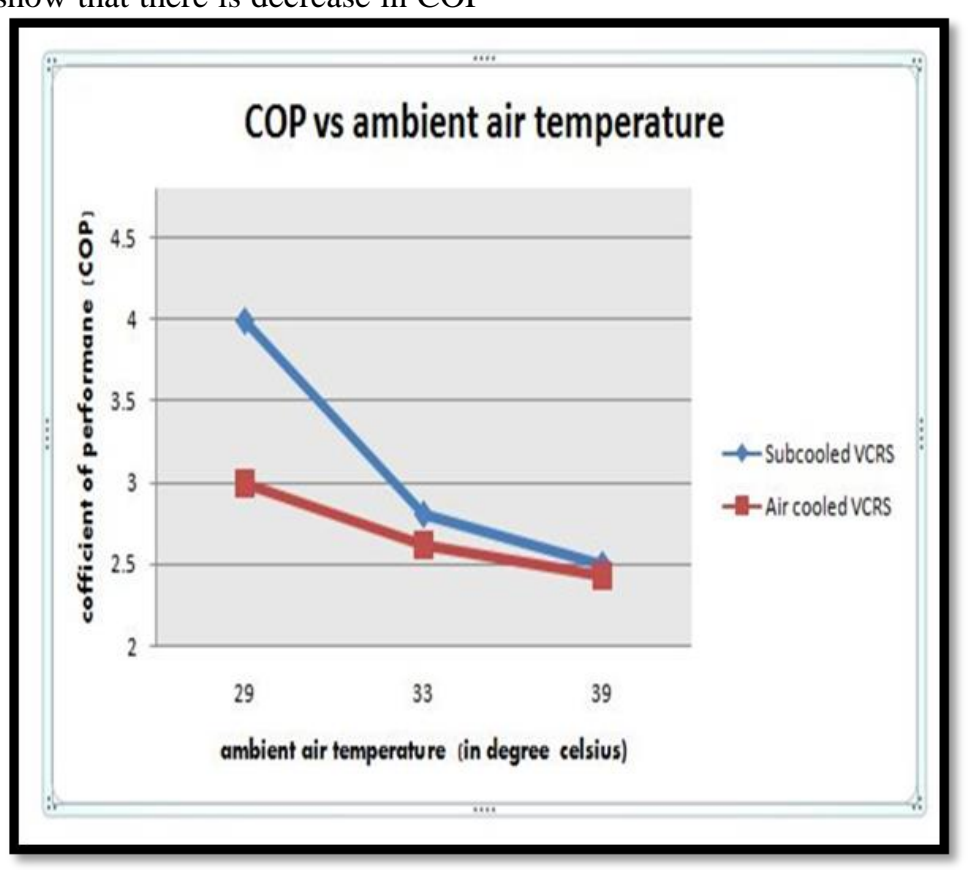

FIGURE 5: Cop variation at different ambient air temperature 


\section{CONCLUSION}

In this experiment a subcooled VCRS with heat exchanger and air simple air cooled VCRS is experimentally investigated. Experimental results show that there is considerable increase in the COP of the subcooled VCRS as compare to air cooled VCRS and further there is significant decrease in compressor work for subcooled vcrs system as compared air cooled vcrs. In case of subcooled VCRS there is an increase in the steady state COP from 3 to 3.9 under the following conditions: the wet-bulb temperature is $21^{\circ} \mathrm{C}$, dry-bulb temperature is $29^{\circ} \mathrm{C}$, air velocity is $2.4 \mathrm{~m} / \mathrm{s}$ and power consumption is decreased by $34 \%$ whereas in case of air cooled VCRS the increase in Compressor work and COP decrease by $26 \%$. The experimental investigation also verifies that condensing temperature and pressure decreases in case of subcooled VCRS system which decreases the compressor work. The subcooled VCRS system thus results in increasing cooling load and decreasing power consumption of the compressor which consequently save enough amount of energy.Thus the use of subcooled system with heat exchanger will reduce the peak load conditions of power network in extreme hot weather conditions because vapour compression air conditioners are the main cause of peak loads.

\section{REFERENCE}

[1] C.E. Groseclose, "Cost comparison of air conditioning refrigerant condensing systems." Refrigeration Engineering, June (1954) 54-58.

[2] Gosney, W.B., "Principles of Refrigeration", Cambridge University Press, Cambridge, U.K.,1982.

[3] R.L. Webb, "A unified theoretical treatment for thermal analysis of cooling towers, evaporative condensers, and fluid coolers" ASHRAE Trans 90 (Part 2B) (1984) 398-415.

[4] McLinden, M.O., "Optimum Refrigerants for Non-Ideal Cycles: An Analysis. Employing Corresponding States $\bullet$, Proceedings of ASHRAEPurdue CFC \& IIR-Purdue Refrigeration Conferences, pp. 69-79, W. Lafayette, IN, July 1990.

[5] Domanski, P.A., Didion, D.A., 1994. Evaluation of suction-line/liquid-line heat exchange in the refrigeration cycle, International Journal of Refrigeration 17, 487-493.

[6] Linton, J.W., Snelson, W.K., Hearty, P. F., 1992. Effect of condenser liquid subcooling on system performance for refrigerants CFC-12, HFC134a and HFC-152a. ASHRAE Transactions 98, $160-146$

[7] Arora C.P., (2001), "Refrigeration and Air conditioning", book. 